Article

\title{
An Analysis of the Economic Effects of Cover Crop Use on Farm Net Returns per Acre in Central Indiana
}

\author{
Megan N. Hughes * and Michael R. Langemeier ${ }^{(D)}$ \\ Department of Agricultural Economics, Purdue University, West Lafayette, IN 47907, USA; \\ mlangeme@purdue.edu \\ * Correspondence: hughe232@purdue.edu
}

Received: 4 June 2020; Accepted: 22 June 2020; Published: 23 June 2020

\begin{abstract}
Utilizing cover crop treatments can have significant agronomic benefits for a farm enterprise. However, implementing this technology introduces additional costs. Data were obtained from a Central Indiana case farm to evaluate the relationship between applied nitrogen and corn yield, and how this relationship is impacted by introducing three different species of cover crops: annual ryegrass, cereal rye, and an oats and radish blend. The resulting information was then translated into a partial budget so that the effects on net returns could be analyzed using historical prices and stochastic modelling. The results showed that the impact on net returns per acre varied among cover crop species. The implementation of annual ryegrass resulted in a negative change to net returns. Conversely, implementing cereal rye or an oats and radish blend resulted in a positive change to net returns, with the largest net benefits accruing to the oats and radish blend.
\end{abstract}

Keywords: cover crops; net returns; partial budget; Indiana; cereal rye; annual rye; oats and radish

\section{Introduction}

The agronomic benefits of cover crops have been extensively studied. Their use can improve soil structure where compaction is prevalent [1,2]. Cover crops may also reduce wind and water erosion [3-5]. Additional benefits to soil health include increasing microbial biomass [6,7], increasing soil organic carbon [4,8], and increasing the amount of available nitrogen [9-11].

Despite evidence of agronomic benefits, the cover crop adoption rates among producers are low. For example, the Census of Agriculture showed that $7.25 \%$ of Indiana cropland was planted to a cover crop in 2017 [12]. Further understanding of how the use of cover crops might benefit a farm are needed to spur the adoption of cover crop technologies [13,14].

Net returns (i.e., a comparison of economic benefits and costs) can be used to measure the economic impacts resulting from the adoption of cover crops. Economic benefits include potentially higher crop yields and lower nitrogen application rates. Adoption costs include seed costs, planting costs, termination costs, and other costs, such as changes in fertilizer costs. Frye et al. [15], Reddy [16], and Mahama et al. [17] evaluated the net returns of utilizing various cover crop species with mixed results. Leguminous cover crops tended to yield positive results in agronomic trials. Frye et al. [15] specifically studied winter cover crops as a source of nitrogen for no-till corn, finding that the use of a hairy vetch cover crop could increase soil productivity over time and reduce the need for nitrogen fertilizer.

Survey methodology can be used to aggregate the experiences of many farmers. Plastina et al. [18] compared cover crop users and non-cover crop users, generating average partial budgets to represent each group. The changes between the two groups were calculated to determine the changes in each line item and the overall net returns associated with cover crop use, followed by corn. The results showed that unless the cover crops were used for grazing or forage, the change to net returns were 
consistently negative across cropping systems. The type of cover crop utilized by the farms surveyed was not explored.

The objective of this paper is to identify the change in net returns, or the overall effect on the bottom line, associated with three different cover crop treatments: annual ryegrass, cereal rye, and an oats and radish blend. A farmer-led agronomic trial is analyzed to identify the relationship between applied nitrogen fertilizer and corn yields. Partial budgets are developed using the relationship between corn yield and nitrogen application rates for each cover crop treatment and information for a case farm. The results are analyzed using historical prices and stochastic modelling to incorporate price risk.

\section{Materials and Methods}

\subsection{Farmer-Led Applied Nitrogen Study}

The data for this study came from a case farm in Hamilton County, Indiana. The field experiment consisted of four treatment groups: no cover crop, annual ryegrass, cereal rye, and an oats and radish blend. The cover crops were planted in the fall after the harvest of the previous cash crop. The predominant soil type of the test plots was Brookston silty clay loam, with some portions graded as a Crosby silt loam. The primary form of applied nitrogen was anhydrous ammonia applied post-emergence.

Nitrogen fertilizer was applied at varying rates across each treatment group. The nitrogen rates used in each year are shown in Table 1 . The nitrogen levels were adjusted each year based on the farmer's experience and expertise. The study took place from 2011 to 2017 on a no-till field with no previous cover crop use. A corn-soybean rotation was used, so the data pertaining to corn yields were collected in 2011, 2013, 2015, and 2017. The descriptive statistics for the yield data for each cover crop across all nitrogen rates is shown in Table 2. In addition to the nitrogen study data, the case farm estimated the change in phosphorus and potassium costs resulting from the adoption of cover crop systems, along with seed and planting costs. A further description of all data used is available [19].

Table 1. Applied Nitrogen Rates by Year.

\begin{tabular}{cccc}
\hline $\mathbf{2 0 1 1}$ & $\mathbf{2 0 1 3}$ & $\mathbf{2 0 1 5}$ & $\mathbf{2 0 1 7}$ \\
\hline 0 & 55 & 55 & 95 \\
65 & 95 & 115 & 115 \\
112 & 115 & 135 & 135 \\
150 & 135 & 175 & 175 \\
160 & 175 & - & - \\
206 & - & - & - \\
\hline
\end{tabular}

Table 2. Descriptive Statistics for Yield Data Across all Nitrogen Rates.

\begin{tabular}{ccccc}
\hline & No Cover & Annual Rye & Cereal Rye & Oats/Radish \\
\hline Mean & 172.86 & 171.39 & 171.68 & 180.46 \\
Standard Deviation & 26.75 & 26.66 & 29.12 & 31.34 \\
Range & $108.40-221.97$ & $109.50-219.38$ & $93.40-218.82$ & $101.60-233.66$ \\
\hline
\end{tabular}

\subsection{Estimation of Net Returns}

The relationship between the applied nitrogen and the subsequent corn yield were estimated using a standard OLS (Ordinary Least Squares) regression for each treatment group. Using a quadratic production function and corn and nitrogen prices, the profit maximizing-or economically optimal-levels of the applied nitrogen and associated corn yields for each treatment group were calculated. The regression used in this model is represented by Equation (1), which also represents the production function. To find the profit maximizing levels, the production function was substituted 
into Equation (2), the standard profit function, set equal to 0 , and solved for $\mathrm{N}$. This process is demonstrated with Equations (3)-(5). The variable descriptions from these equations are listed in Table 3. The historical corn prices used were from the National Agricultural Statistics Service [20] and the historical nitrogen prices were from the Economic Research Service [21].

$$
\begin{gathered}
\text { yield }_{\text {corn }}=\beta_{0}+\beta_{1} N+\beta_{2} N^{2}, \\
\pi=p Y-r N \\
\pi=p\left(a+b N+c N^{2}\right)-r N \\
0=p b+2 p c N-r \\
N^{*}=\frac{r}{2 p c}-\frac{b}{2 c}
\end{gathered}
$$

Table 3. Variable Descriptions for Regression and Profit Equations.

\begin{tabular}{ccc}
\hline Variable & Meaning & Source \\
\hline yield $_{\text {corn }}$ & Reported yield of corn in bushels/acre & Case Farm \\
$N$ & Reported level of applied nitrogen in pounds/acre & Case Farm \\
$N^{2}$ & Square of N & Case Farm \\
$\pi$ & Profit & Computed \\
$p$ & Price of corn per bushel & USDA-NASS \\
$Y$ & Estimated corn yield represented by the production function & Regression \\
$r$ & Price of nitrogen fertilizer per pound & USDA-NASS \\
$N^{*}$ & Optimal level of applied nitrogen in pounds/acre & Computed \\
$a$ & Intercept of the production function & Regression \\
$b$ & Coefficient of the linear term of the production function & Regression \\
$c$ & Coefficient of the quadratic term of the production function & Regression \\
\hline
\end{tabular}

* Asterisk denotes the difference between reported $\mathrm{N}$ levels and the optimal level that was solved for via Equations (2)-(5).

To determine the impact on net returns, a partial budget consisting of all the budget line items that were affected by cover crop use was constructed. Table 4 lists the line items and a description of how each one was calculated. The cost categories included seed cost, planting cost, cover crop termination cost, and fertilizer cost. To calculate the changes in cash crop yield and the changes in nitrogen cost, the profit maximizing level of the no cover treatment was subtracted from that of the cover crop treatment. It is worth noting that because the corn followed soybean in rotation, there would be a surplus of available nitrogen [22]. The costs other than nitrogen were based on the data provided by the case farm. The historical corn and nitrogen price combinations from each year of the study were used as inputs for the partial budget.

\subsection{Stochastic Incorporation of Price Risk}

Using Palisade's @Risk software (version 7.6.0), it was possible to create a distribution of the potential net change in net returns based on the probable corn and nitrogen prices. @Risk is a Microsoft Excel add-in that allows users to simulate outcomes by replacing input variables with pseudorandom generated inputs, with this generation guided by parameters set by the user. A simulation runs for a given number of iterations, each time using a different set of input values. This produces a distribution of possible outcome values.

A Monte Carlo simulation using 1000 iterations was run. Probability distributions for corn price and nitrogen fertilizer price were the parameters used to guide the generation of input values for these variables. The software tracked the output value of net change in net returns per acre for each iteration. 
Table 4. Description of Partial Budget Line Items.

\begin{tabular}{|c|c|c|}
\hline Line Item & Calculation & Source \\
\hline \multicolumn{3}{|l|}{ Changes in Revenues } \\
\hline Change in Cash Crop Yield- Corn & (Yield with Cover-Yield with No Cover) ${ }^{*}$ Corn Price & Regression/USDA-NASS \\
\hline \multicolumn{3}{|l|}{ Changes in Costs } \\
\hline \multicolumn{3}{|l|}{ Cover Crop Planting } \\
\hline Seeds & Cost of Seed per Acre & Case Farm \\
\hline \multicolumn{3}{|l|}{ Planting Costs } \\
\hline Tractor Hours & Rate of Input per Unit ${ }^{*}$ Units of Input per Acre & Case Farm \\
\hline Labor & Rate of Input per Unit * Units of Input per Acre & Case Farm \\
\hline Fuel & Rate of Input per Unit ${ }^{*}$ Units of Input per Acre & Case Farm \\
\hline Planter Repairs/Wear & Rate of Input per Unit * Units of Input per Acre & Case Farm \\
\hline \multicolumn{3}{|l|}{ Cover Crop Termination } \\
\hline Herbicide Cost & Cost of Herbicide per Acre & Case Farm \\
\hline Cost to Apply & Rate of Input per Unit* Units of Input per Acre & Case Farm \\
\hline Other Termination Costs & Rate of Input per Unit* Units of Input per Acre & Case Farm \\
\hline \multicolumn{3}{|l|}{ Changes to Other Costs } \\
\hline Nitrogen Costs & (Nitrogen with Cover-Nitrogen with No Cover) ${ }^{*}$ Nitrogen Price & Regression/USDA-NASS \\
\hline Other Fertilizer Costs (P\&K) & (Other Costs with Cover-Other Costs with No Cover) * Price of Other & Case Farm \\
\hline Net Change in Net Returns & Change in Revenues-Change in Costs & Budget \\
\hline
\end{tabular}

The probability distribution was fitted using three different distributions for the historical corn and nitrogen prices from 1996-2018. The different distributions were utilized to check the fragility of the results to the choice of probability distributions. The first fit both variables with a normal distribution. The second fit both variables with a triangular distribution, which can be summarized using information pertaining to the minimum value, maximum value, and most likely value for each variable. The third set used the distribution fitting tool to determine what distribution best fit the data: a pareto distribution for corn prices and uniform distribution for nitrogen prices.

The correlation between the corn and nitrogen prices was accounted for by using the correlation tool in @Risk. The corn and nitrogen prices were adjusted to account for the 2007 price break [23] by adjusting the pre-2007 mean to match the mean of the post-2007 prices.

\section{Results}

\subsection{Profit Maximizing Applied Nitrogen Levels and Associated Corn Yields}

The production functions estimated from the applied nitrogen study are graphed in Figure 1. This provides a visual demonstration of the impacts of each treatment on production capacity. It is evident that the oats/radish blend had a higher production maximum than the other treatment groups. The cereal rye treatment peaked at a slightly lower applied nitrogen rate than the annual rye treatment or the no cover control group.

Table 5 places the results of the profit maximization for each cover treatment side by side. The average corn and nitrogen prices using data for 2011, 2013, 2015, and 2017 were used to generate the results in Table 5. It is evident that the profit maximizing corn yields for the cereal rye and oats/radish blend cover crop treatments were higher than those of the no-cover treatment. The cereal rye had a $4.32 \%$ lower profit maximizing applied nitrogen level than the no cover treatment. The annual rye and oats/radish blend both required more applied nitrogen than the no cover treatment; however, the oats/radish blend resulted in a notably higher corn yield than the no cover treatment.

Table 5. Profit Maximizing Results for Each Cover Crop Treatment.

\begin{tabular}{ccc}
\hline Treatment & Nitrogen Rate (Lbs/Acre) & Yield (Bu/Acre) \\
\hline No Cover & 137.15 & 183.06 \\
Annual Rye & 140.98 & 183.85 \\
Cereal Rye & 131.22 & 185.19 \\
Oats/Radish & 139.58 & 192.99 \\
\hline
\end{tabular}




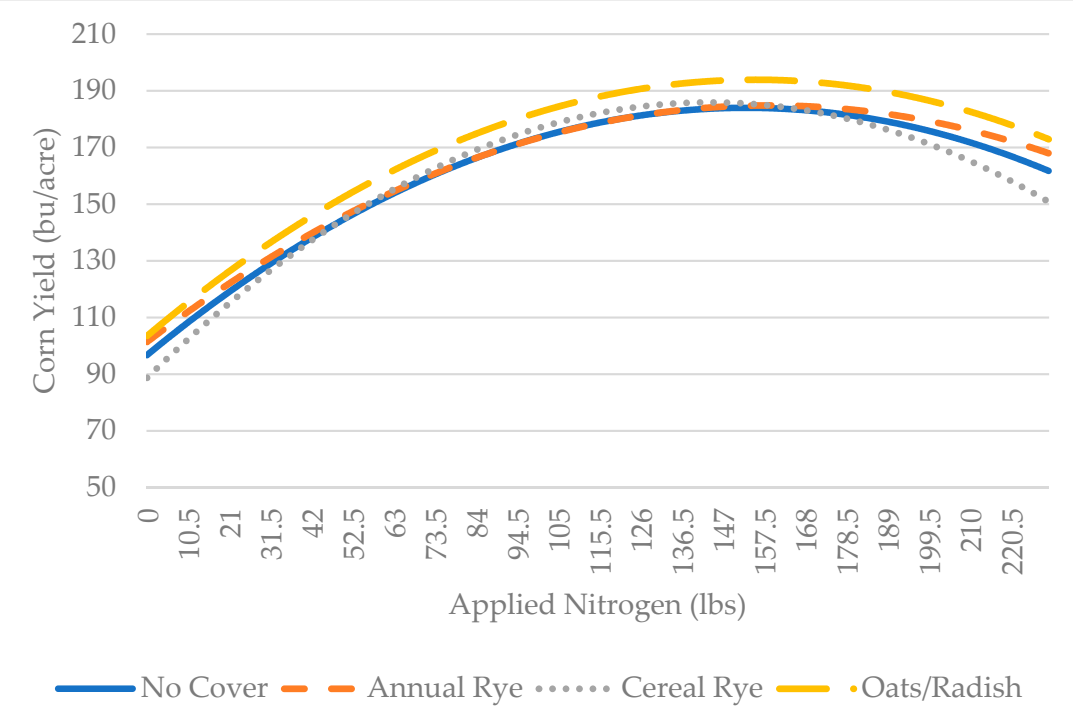

Figure 1. The relationship between applied nitrogen and corn yield is plotted for each treatment.

\subsection{Static Budget Analysis}

The partial budget reported values as changes from the no cover treatment. For example, the net change in net returns per acre was the value by which the net returns per acre were predicted to change when the cover crop treatment was implemented. A positive value indicated an increase to the dollar value of a line item, while a negative value indicated a decrease. A decrease in "Changes in Costs" would mean that the costs decreased, resulting in an increase to net returns per acre.

Table 6 illustrates a sample budget using the average corn and nitrogen prices from 2011, 2013, 2015, and 2017. Seed cost, planting cost, termination costs, and phosphorus and potassium cost estimates were obtained from the case farm. The cover crops fit into the case farm's no-till practices, so the termination costs were zero. Table 7 presents the change in units for each item reported in Table 6.

Table 6. Sample Partial Budget.

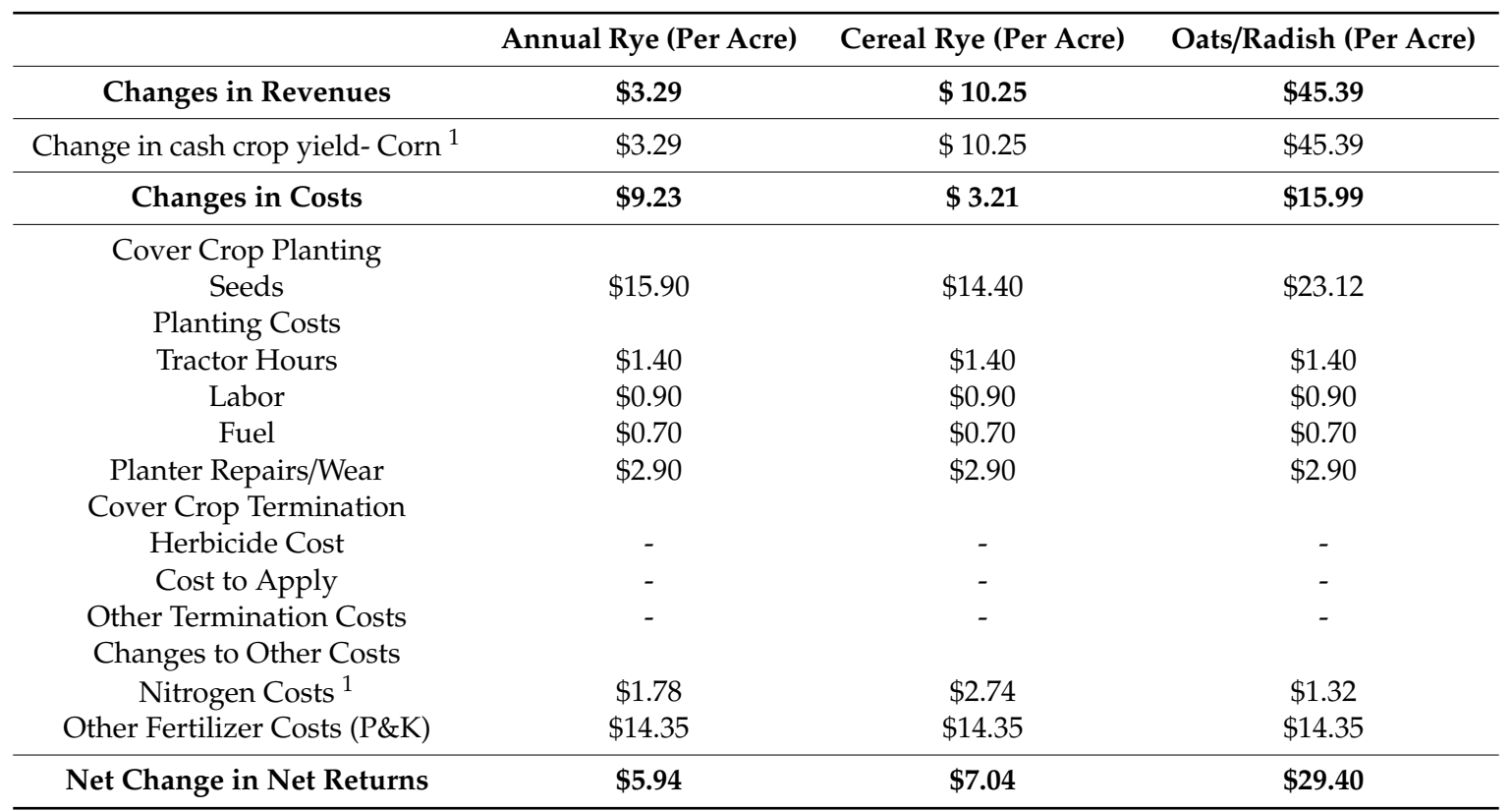

${ }^{1}$ The average of corn and nitrogen prices from 2011, 2013, 2015, and 2017 was used as the corn price (\$4.57) and the nitrogen price $(\$ 0.53)$ for calculations in this table. 
Table 7. Adjustments of Line Item Units.

\begin{tabular}{cccc}
\hline & $\begin{array}{c}\text { Annual Rye } \\
\text { (per Acre) }\end{array}$ & $\begin{array}{c}\text { Cereal Rye } \\
\text { (per Acre) }\end{array}$ & $\begin{array}{c}\text { Oats/Radish } \\
\text { (per Acre) }\end{array}$ \\
\hline Change in cash crop yield- Corn (bu) & 0.72 & 2.24 & 9.93 \\
\hline Cover Crop Planting & & & \\
Seeds (lbs) & 15 & 40 & 34 \\
Planting Costs & & & \\
Tractor Hours & 0.04 & 0.04 & 0.04 \\
Labor (Hours) & 0.06 & 0.06 & 0.06 \\
Fuel (Gallons) & 0.20 & 0.20 & 0.20 \\
Planter Repairs/Wear & 0.58 & 0.58 & 0.58 \\
Cover Crop Termination & & & - \\
Herbicide Cost & - & - & - \\
$\quad$ Cost to Apply & - & - & - \\
Other Termination Costs & - & -5.07 & 2.44 \\
Changes to Other Costs & & -50 & -50 \\
Nitrogen Costs (lbs) & 3.30 & -50 &
\end{tabular}

The corn and nitrogen prices used, as well as the change in net returns per acre for each year of the study, are reported in Table 8. The annual rye was projected to decrease net returns under every scenario. Conversely, both the cereal rye and the oats/radish blend increased net returns under every scenario. Due to declining corn prices, the projected net returns for cereal rye and the oat/radish blend decreased from 2011 to 2017.

Table 8. Changes in Net Returns per Acre for Cover Crop Treatments.

\begin{tabular}{cccccc}
\hline Year & Corn Price $\mathbf{( \$ / B u )}$ & Nitrogen Price $\mathbf{( L b s / B u )}$ & Annual Rye & Cereal Rye & Oats/Radish \\
\hline 2011 & $\$ 6.31$ & $\$ 0.59$ & $\$ 4.85$ & $\$ 11.19$ & $\$ 46.57$ \\
2013 & $\$ 4.47$ & $\$ 0.61$ & $\$ 6.25$ & $\$ 7.17$ & $\$ 28.24$ \\
2015 & $\$ 3.92$ & $\$ 0.53$ & $\$ 6.38$ & $\$ 5.53$ & $\$ 22.97$ \\
2017 & $\$ 3.56$ & $\$ 0.41$ & $\$ 6.24$ & $\$ 4.11$ & $\$ 19.69$ \\
\hline
\end{tabular}

\subsection{Stochastic Budget Analysis}

The stochastic model accounted for a wide distribution of corn and nitrogen price combinations. The input variables are illustrated in Table 9, and the outputs are illustrated in Table 10. The results from the stochastic analysis lined up with those of the static analysis. The 5\% and 95\% columns represented the 5th and 95th percentiles of the 1000 iterations of the simulations.

Table 9. Distributions of Stochastic Inputs.

\begin{tabular}{cccccc}
\hline & Min & Mean & Max & $\mathbf{5 \%}$ & $\mathbf{9 5 \%}$ \\
\hline Normal-Normal & & & & & \\
$\quad$ Corn Prices & $\$ 1.81$ & $\$ 4.54$ & $\$ 7.42$ & $\$ 3.06$ & $\$ 5.97$ \\
Nitrogen Prices & $\$ 0.24$ & $\$ 0.50$ & $\$ 0.74$ & $\$ 0.37$ & $\$ 0.63$ \\
Triangular-Triangular & & & & & \\
$\quad$ Corn Prices & $\$ 3.56$ & $\$ 4.85$ & $\$ 7.41$ & $\$ 3.65$ & $\$ 6.61$ \\
Nitrogen Prices & $\$ 0.40$ & $\$ 0.50$ & $\$ 0.68$ & $\$ 0.41$ & $\$ 0.62$ \\
Pareto-Uniform & & & & & \\
$\quad$ Corn Prices & $\$ 3.56$ & $\$ 4.59$ & $\$ 23.59$ & $\$ 3.60$ & $\$ 7.13$ \\
Nitrogen Prices & $\$ 0.39$ & $\$ 0.52$ & $\$ 0.64$ & $\$ 0.41$ & $\$ 0.63$ \\
\hline
\end{tabular}


Table 10. Stochastic Distributions of Net Change to Net Returns per Acre.

\begin{tabular}{cccccc}
\hline & Min & Mean & Max & $\mathbf{5 \%}$ & $\mathbf{9 5 \%}$ \\
\hline Annual Rye & & & & & \\
Normal-Normal & $\$ 7.63$ & $\$ 5.84$ & $\$ 4.37$ & $\$ 6.80$ & $\$ 4.93$ \\
Triangular-Triangular & $\$ 6.91$ & $\$ 5.59$ & $\$ 3.78$ & $\$ 6.41$ & $\$ 4.44$ \\
$\quad \begin{array}{c}\text { Pareto-Uniform } \\
\text { Cereal Rye }\end{array}$ & $\$ 6.86$ & $\$ 5.87$ & $\$ 7.47$ & $\$ 6.65$ & $\$ 4.27$ \\
$\quad$ Normal-Normal & $\$ 0.04$ & $\$ 6.79$ & $\$ 14.30$ & $\$ 3.12$ & $\$ 10.41$ \\
Triangular-Triangular & $\$ 4.08$ & $\$ 7.45$ & $\$ 13.53$ & $\$ 4.45$ & $\$ 11.61$ \\
$\quad$ Pareto-Uniform & $\$ 4.05$ & $\$ 6.98$ & $\$ 50.14$ & $\$ 4.39$ & $\$ 13.03$ \\
$\quad$ Oats/Radish & & & & & \\
$\quad$ Normal-Normal & $\$ 2.39$ & $\$ 29.23$ & $\$ 57.33$ & $\$ 14.80$ & $\$ 43.21$ \\
Triangular-Triangular & $\$ 19.65$ & $\$ 32.34$ & $\$ 57.55$ & $\$ 20.42$ & $\$ 49.71$ \\
$\quad$ Pareto-Uniform & $\$ 19.41$ & $\$ 29.61$ & $\$ 218.15$ & $\$ 19.93$ & $\$ 54.55$ \\
\hline
\end{tabular}

Using an annual rye treatment resulted in a negative change in the net returns per acre across almost every iteration of the simulations, finding a positive outcome in just $0.2 \%$ of the pareto-uniform iterations. Of those iterations with a positive outcome, the average corn price was $\$ 20.99-$ well above what can be considered realistic.

The use of a cereal rye treatment projected a positive change in net returns per acre, with the mean changes to net returns ranging from $\$ 6.79$ to $\$ 7.45$. The oats and radish blend also showed a positive change in net returns per acre, with a mean of $\$ 29.23$ to $\$ 32.93$.

\section{Discussion}

This paper investigates the effects of introducing cover crop use on net returns per acre for corn. The analysis compares the use of three cover crop treatments to no cover crop use by first estimating changes in optimal fertilizer input and resulting yield levels, and then incorporating these estimations into a partial budget. We combine previous work by Frye et al. [15], linking nitrogen application and cover crops, and Plastina et al. [18], who utilize cover crop partial budgets.

In optimizing the estimated production functions, it was found that only the oats and radish blend treatment resulted in a notably higher yield when compared with no cover, while the cereal rye treatment required less applied nitrogen to obtain profit-maximizing yields when compared with no cover. The annual rye treatment required more applied nitrogen to achieve a similar yield as the no cover. The static partial budget analysis showed that the use of an annual rye cover crop following this production function would result in negative net returns for all four years of the study, while the use of cereal rye or an oats and radish blend would result in positive net returns. The stochastic analysis showed that over a wide range of corn and nitrogen prices and multiple estimation techniques, these results held true.

The results differ from Plastina et al. [18], showing that cover crops have the potential to provide positive returns, even when not used for forage and grazing. The impact on net returns in this study depends on the cover crop used. The adoption of annual rye resulted in negative net returns (i.e., adoption costs were larger than the economic benefits). The net returns for cereal rye and an oats and radish blend were positive, with the largest net returns accruing to the oats/radish blend.

The results found here are based on four years of yield and cost data from one case farm in Central Indiana. The implications of the study are relevant to regions with a similar agricultural climate. Further research is needed to determine the impacts in different climates, or under different management regimes. Further analysis that broadens the data set and scope of analysis is also required to wholly identify the economic impacts of cover crop use.

Author Contributions: M.N.H. and M.R.L. conducted the conceptualization, methodology, investigation, writing, and editing of this article jointly. All authors have read and agreed to the published version of the manuscript.

Funding: This research received no external funding. 
Acknowledgments: The authors would like to thank the proprietors of the case farm for providing data and expertise on the projects.

Conflicts of Interest: The authors declare no conflict of interest.

\section{References}

1. Calonego, J.C.; Raphael, J.P.; Rigon, J.P.; de Oliveira Neto, L.; Rosolem, C.A. Soil Compaction Management and Soybean Yields with Cover Crops under No-Till and Occasional Chiseling. Eur. J. Agron. 2017, 85, 31-37. [CrossRef]

2. Williams, S.M.; Weil, R.R. Crop Cover Root Channels May Alleviate Soil Compaction Effects on Soybean Crop. Soil Sci. Soc. Am. J. 2004, 68, 1403-1409. [CrossRef]

3. Blanco-Canqui, H.; Holman, J.D.; Schlegel, A.J.; Tatarko, J.; Shaver, T.M. Replacing Fallow with Cover Crops in a Semiarid Soil: Effects on Soil Properties. Soil Sci. Soc. Am. J. 2013, 77, 1026-1034. [CrossRef]

4. Blanco-Canqui, H.; Shaver, T.M.; Lindquist, J.L.; Shapiro, C.A.; Elmore, R.W.; Francis, C.A.; Hergert, G.W. Cover Crops and Ecosystem Services: Insights from Studies in Temperate Soils. Agron. J. 2015, 106, 2449-2474. [CrossRef]

5. De Baets, S.; Poesen, J.; Meersmans, J.; Serlet, L. Cover Crops and their Erosion-Reducing Effects during Concentrated Flow Erosion. CATENA 2011, 85, 237-244. [CrossRef]

6. Faé, G.; Sulc, R.M.; Barker, D.J.; Dick, R.P.; Eastridge, M.L.; Lorenz, N. Integrating Winter Annual Forages into a No-Till Corn Silage System. Agron. J. 2009, 101, 1286-1296. [CrossRef]

7. Kirchner, M.J.; Wollum, A.G., II; King, L.D. Soil Microbial Populations and Activities in Reduced Chemical Input Agroecosystems. Soil Sci. Soc. Am. J. 1993, 57, 1289-1295. [CrossRef]

8. Mullen, M.D.; Melhorn, C.G.; Tyler, D.D.; Duck, B.N. Biological and Biochemical Soil Properties in No-Till Corn with Different Cover Crops. J. Soil Water Conser. 1998, 53, 219-224.

9. Kaspar, T.C.; Singer, J.W. The Use of Cover Crops to Manage. Soil. In Soil Management: Building a Stable Base for Agriculture; Hatfield, J.L., Sauer, T.J., Eds.; Soil Science Society of America: Madison, WI, USA, 2011; pp. 321-337.

10. Parr, M.; Grossman, J.M.; Reberg-Horton, S.C.; Brinton, C.; Crozier, C. Nitrogen Delivery from Legume Cover Crops in No-Till Organic Corn Production. Agron. J. 2011, 103, 1578-1590. [CrossRef]

11. Quemada, M.; Baranski, M.; Nobel-de Lange, M.N.J.; Vallejo, A.; Cooper, J.M. Meta-Analysis of Strategies to Control Nitrate Leaching in Irrigated Agricultural Systems and their Effects on Crop Yield. Agric. Ecosyst. Environ. 2013, 174, 1-10. [CrossRef]

12. USDA. 2017 Census of Agriculture, Indiana State and County Data. Available online: https://www.nass. usda.gov/Publications/AgCensus/2017/Full_Report/Census_by_State/Indiana/ (accessed on 17 April 2019).

13. CTIC. Report of the 2016-17 National Cover Crop Survey; Joint Publication of the Conservation Technology Information Center, the North Central Region Sustainable Agriculture Research and Education Program, and the American Seed Trade Association: West Lafayette, IN, USA, 2017.

14. Roesch-McNally, G.E.; Basche, A.D.; Arbuckle, J.G.; Tyndall, J.C.; Miguez, F.E.; Bowman, T.; Clay, R. The Trouble with Cover Crops: Farmers' Experiences with Overcoming Barriers to Adoption. Renew. Agric. Food Syst. 2018, 33, 322-333. [CrossRef]

15. Frye, W.W.; Smith, W.G.; Williams, R.J. Economics of Winter Cover Crops as a Source of Nitrogen for No-Till Corn. J. Soil Water Conser. 1985, 40, 246-249.

16. Reddy, K.N. Effects of Cereal and Legume Cover Crop Residues on Weeds, Yield, and Net Return in Soybean (Glycine max). Weed Technol. 2001, 15, 660-668. [CrossRef]

17. Mahama, G.Y.; Prasad, P.V.; Roozeboom, K.L.; Nippert, J.B.; Rice, C.W. Response of Maize to Cover Crops, Fertilizer Nitrogen Rates, and Economic Return. Agron. J. 2016, 108, 17-31. [CrossRef]

18. Plastina, A.; Liu, F.; Sawadgo, W.; Miguez, F.E.; Carlson, S.; Marcillo, G. Annual Net Returns to Cover Crops in Iowa. J. Appl. Farm Econ. 2018, 2, 19-36.

19. Hughes, M.N. Exploring the Effects of Cover Crop Use on Farm Profitability in Central Indiana. M.S. Thesis, Purdue University Graduate School, West Lafayette, IN, USA, May 2020.

20. Quick Stats. USDA National Agricultural Statistics Service. Available online: https://www.nass.usda.gov/ Quick_Stats/ (accessed on 3 September 2019). 
21. USDA. Fertilizer Use and Price. Available online: https://www.ers.usda.gov/data-products/fertilizer-useand-price/ (accessed on 3 September 2019).

22. Gentry, L.E.; Below, F.E.; David, M.B.; Bergerou, J.A. Source of the Soybean N Credit in Maize Production. Plant Soil 2001, 236, 175-184. [CrossRef]

23. Wallander, S.; Claassen, R.; Nickerson, J.C. The Ethanol Decade: An Expansion of U.S. Corn Production, 2000-2009. SSRN Electr. J. 2011. [CrossRef] 